\title{
Perlindungan Hukum Terhadap Pekerja Migran Sektor Informal dalam Perspektif Teori Bekerjanya Hukum di Masyarakat
}

\author{
Henny Natasha Rosalina1*, Lazarus Tri Setyawanta2 \\ 1Fakultas Hukum, Univesitas 17 Agustus 1945 Semarang \\ 2Fakultas Hukum, Universitas Diponegoro \\ *natasha.rossalina@gmail.com
}

\begin{abstract}
The protection and fulfillment of the rights of Indonesian migrant workers is a responsibility that must be carried out by the government, together with authorized institutions and agencies. Protection and fulfillment of rights are specifically directed at Indonesian migrant workers in the informal sector who work as domestic workers because they are very vulnerable to treatment in the form of violence, torture, and punishment. This article aims to examine the effectiveness of the protection and fulfillment of the rights of Indonesian migrant workers based on the Theory of Law in Society in Law No.18 of 2017. The research method used is normative juridical research, which is based on a legal approach and a case approach. The results of this study that the legal rules that have been perfected in Law No.18 of 2017 have clear legal rules. The problems that often arise with Indonesian migrant workers are caused by negligence from the government and institutions in providing protection and fulfillment of the rights and attitudes of the public in filtering out the right information. The attitude of the community must be accompanied by monitoring and cooperation by the government and institutions, because the community, whether they are prospective migrant workers, migrant workers, and their families in the informal sector, are still vulnerable to becoming victims by irresponsible parties.
\end{abstract}

\section{Keywords: Indonesian Migrant Workers; Informal Sector; Legal Protection.}

\begin{abstract}
ABSTRAK
Perlindungan dan pemenuhan hak pekerja migran Indonesia merupakan tanggung jawab yang harus dilakukan pemerintah bersama lembaga dan badan-badan yang berwenang. Pelindungan dan pemenuhan hak secara khusus ditujukan kepada pekerja migran Indonesia di sektor informal yang bekerja sebagai pekerja rumah tangga karena mereka rentan sekali mendapatkan perlakuan berupa kekerasan, penyiksaan, dan penghukuman. Artikel ini bertujuan untuk mengkaji efektifitas pelindungan dan pemenuhan hak pekerja migran Indonesia berdasarkan Teori Bekerjanya Hukum di Masyarakat didalam UU No.18 Tahun 2017. Metode penelitian yang digunakan adalah penelitian yuridis normatif, dimana berbasis pendekatan undang-undang dan pendekatan kasus. Hasil penelitian ini bahwa aturan hukum yang telah disempurnakan didalam UU No.18 Tahun 2017 memiliki aturan hukum yang jelas. Seringnya persoalan yang muncul terhadap pekerja migran Indonesia disebabkan karena kelalaian dari pemerintah maupun lembaga dalam memberikan pelindungan dan pemenuhan hak serta sikap masyarakat dalam menyaring informasi yang tepat. Sikap masyarakat harus dibarengi dengan pantauan dan kerjasama oleh pemerintah dan lembaga, karena masyarakat, baik mereka calon pekerja migran, pekerja migran,dan keluarganya secara khusus di sektor informal, masih rentan menjadi korban oleh pihak tidak bertanggung jawab.
\end{abstract}

Kata Kunci: Pekerja Migran Indonesia; Sektor Informal ; Perlindungan Hukum. 


\section{A. PENDAHULUAN}

Setiap manusia hidup membutuhkan pekerjaan untuk memenuhi setiap kebutuhan hidupnya. Kebutuhan manusia dapat terpenuhi dengan melakukan suatu pekerjaan. Pekerjaan yang dilakukan tersebut untuk mendapatkan upah guna memenuhi kebutuhan hidupnya, baik untuk diri sendiri maupun keluarga. Berdasarkan Pasal 27 ayat (2) UUD NRI Tahun 1945 yang menyatakan bahwa "Setiap warga negara berhak atas pekerjaan dan penghidupan yang layak bagi kemanusiaan." Adanya keterbatasan lapangan kerja dan kondisi perekonomian yang kurang menarik di negara asal, memicu orang-orang mencari pekerjaan di negara lain, sehingga memicu mobilitas tenaga kerja (Hidayat, 2017). Terjadinya mobilitas tenaga kerja migran tersebut terus mengalami peningkatan serta memicu pertumbuhan angkatan kerja dan ketersediaan lapangan pekerjaan domestik (Hadi, 2008).

Terjadinya mobilitas pekerja migran ke luar negeri membuat Pemerintah Indonesia harus memenuhi setiap hak dari pekerja migran tersebut. Banyaknya mobilitas pekerja migran ke luar negeri ini disebabkan karena kualitas hidup yang ditawarkan di luar negeri lebih tinggi (Wright, \& Clibborn, 2019). Namun hal ini tidak sebanding dengan terdapatnya kasus kekerasan yang terjadi terhadap pekerja migran di luar negeri mengharuskan pemerintah untuk memperhatikan kelangsungan hidup para pekerja migran. Permasalahan yang terjadi terhadap tenaga kerja migran Indonesia diluar negeri setidaknya ada beberapa kasus, seperti kasus penganiayaan, pelecehan seksual, adanya kasus yang melibatkan dipidanaya para pekerja migran, kasus gaji yang tidak dibayarkan, sampai kepada kasus pemutusan hubungan kerja secara sepihak (Arpanggi,2016).

Pelindungan pekerja migran pada dasarnya telah diatur didalam Pasal 1 ayat (5) Undang-Undang No.18 Tahun 2017, dimana berbunyi, "Pekerja Migran Indonesia adalah segala upaya untuk melindungi kepentingan calon pekerja migran Indonesia dan/atau Pekerja Migran Indonesia dan keluarganya dalam mewujudkan terjaminnya pemenuhan haknya dalam keseluruhan kegiatan sebelum bekerja, selama bekerja, dan setelah bekerja dalam aspek hukum, ekonomi, dan sosial."

Dibutuhkannya peran Pemerintah dalam melindungi dan memenuhi hak-hak para pekerja migran dikarenakan kondisi ini melibatkan hubungan antara negara. Menurut Zainal Asikin, "Dilihat dari segi sosial dan ekonomi, kedudukan pekerja migran tidaklah bebas. Sebagai orang yang tidak memiliki pilihan bekal hidup, para pekerja migran terpaksa bekerja kepada orang lain. Kedudukan majikan pada dasarnya menentukan aturan dan perjanjian kerja. Oleh karena itu peran Pemerintah sangatlah diperlukan untuk memberikan Pelindungan hukum kepada para pekerja migran karena status mereka sangatlah terbatas. Hal inilah menyebabkan bentuk Pelindungan hukum iniberkaitan dengan kekuasaan" (Asikin, 2004).

Pekerja migran pada dasarnya di klasifikasi 
Jurnal Pembangunan Hukum Indonesia

Volume 2, Nomor 2, Tahun 2020
Program Studi Magister Ilmu Hukum Fakultas Hukum Universitas Diponegoro menjadi dua, yaitu pekerja migran sektor formal dan pekerja migran sektor informal. Pekerja migran sektor formal merupakan pekerja migran dengan kualifikasi yang cukup ketat, dimana mereka yang menjadi calon pekerja memiliki jenjang pendidikan menengah keatas, memiliki keahlian, serta pengalaman kerja. Sedangkan pekerja migran informal merupakan pekerja migran dengan tingkat pendidikan menengah kebawah serta sebagaian dari mereka tidak memiliki pengalaman pekerjaan (Prastiwi,2016). Terhadap klasifikasi pekerja migran ini, cenderung pekerja migran di sektor informal sering mengalami kekerasan dan pelanggaran terhadap hak-haknya karena minimnya pengetahuan mereka.

Banyaknya persoalan yang terjadi pada pekerja migran di sektor informal, seperti berstatus ilegal dan tidak memiliki keterampilan menyebabkan terjadinya beberapa perlakuan buruk terjadi kepada mereka. Berdasarkan latar belakang permasalahan tersebut, perlu adanya peran serta pemerintah dan masyarakat dalam upaya mengurangi angka kekerasan yang terjadi pada para pekerja migran di sektor informal ditinjau menggunakan Teori Bekerjanya Hukum di Masyarakat menurut Seidman $\&$ Chambliss. Adapun teori ini untuk melihat bekerja efektifnya aturan hukum dan penegakan yang dibuat dengan tiga faktor, yaitu Lambaga Pembuat Peraturan (Law Making Process), Lembaga Penerap Peraturan (Law Implementating Process), dan Pemegang Peran (Role Occupant). Berdasarkan teori tersebut, melihat bagaimana pembuat undangundang serta lembaga penerap peraturan bertindak menjalankan fungsi-fungsi tersebut, dimana hal ini dengan melihat keseluruhan kompleks sosial, politik, ideologi dan lainnya sebagai umpan balik didalam pemegang peran (Seidman, \& Chamblis,1971). Pekerja migran dalam hal ini dilihat sebagai pemegang peran.

Berdasarkan latar belakang tersebut, terhadap kesenjangan yang terjadi antara perlakuan pekerja migran sektor formal dan informal, dimana bentuk perlakuan terhadap Pelindungan dan pemenuhan hak pekerja migran sektor informal sering terabaikan. Maka dalam penelitian ini permasalahan yang hendak dikaji yakni mengenai bentuk Pelindungan dan pemenuhan hak terhadap pekerja migran sektor informal, serta bagaimana analisis yuridis pelindungan dan pemenuhan hak pekerja migran Indonesia sektor informal berdasarkan Teori Bekerjanya Hukum di Masyarakat.

Penelitian mengenai Pelindungan dan pemenuhan hak pekerja migran di sektor informal belum pernah dibahas pada penelitian sebelumnya. Adapun penelitian oleh Lustina Fajar Prastiwi berjudul "Analisis Pekerja Migran dan Non-Migran Perkotaan Pada Sektor Formal dan Sektor Informal di Inndonesia" membahas dalam perspektif ekonomi, dimana tinjauannya analisis probabilitas pekerja migran di perkotaan (Prastiwi, 2016). Pembaharuan dalam penelitian ini bahwa kajian penelitian lebih difokuskan kepada sektor informal, dimana pembahasan yang diangkat berdasarkan sudut pandang hukum.

Penelitian oleh Safrida Yusitarani dan 
Jurnal Pembangunan Hukum Indonesia

Volume 2, Nomor 2, Tahun 2020
Program Studi Magister Ilmu Hukum Fakultas Hukum Universitas Diponegoro
Nabitatus Sa'adah berjudul "Analisis Yuridis Pelindungan Hukum Tenaga Migran Korban Peerdagangan Manusia Oleh Pemerintah Indonesia" membahas mengenai bentuk Pelindungan tenaga kerja migran yang dilakukan pemerintah dalam rangka memberantas perdagangan manusia (Yusitarani, Sa'adah, 2020). Pembaharuan dalam penelitian ini lebih memfokuskan kepada bentuk Pelindungan yang dilakukan pemerintah terhadap pekerja migran di sektor informal, atas bentuk kekerasan yang terjadi pada pekerja migran.

Penelitian oleh Arpanggi berjudul "Pelindungan Hukum Terhadap Tenaga Kerja Indonesia Di Luar Negeri" membahas peran pemerintah dalam melindungi tenaga kerja Indonesia di luar negeri, dimana kajian pembahasannya ditinjau secara umum berdasarkan UU No.39 Tahun 2004 (Arpanggi,2016). Adapun pembaharuan dalam penelitian ini akan mengkaji bentuk Pelindungan pekerja migran berdasarkan UU No.18 Tahun 2017 tentang Pelindungan Pekerja Migran, serta kajiannya hanya berfokus pada pekerja migran di sektor informal.

Penelitian oleh Anis Widyawati berjudul "Legal Protection Model for Indonesian Migrant Workers", membahas mengenai jenis Pelindungan hukum yang dilakukan terhadap pekerja migran (Widyawati, 2018). Pembaharuan dalam penelitian ini akan mengkaji bentuk Pelindungan berdasarkan teori bekerjanya hukum di masyarakat, dimana walaupun probelmatika yang terjadi pada pekerja migran memiliki kesamaan, namun analisis akan dikaji berdasarkan tinjauan teori serta undang-undang baru yang diberlakukan Indonesia.

Penelitian oleh Ved. P. Nanda berjudul "The Protection of Rights of Migrant Workers : Unfinished Business", dimana kajian penelitian ini membahas ketidakpastian Pelindungan pekerja migran didalam konvensi, dimana terdapat ambiguitas serta penerapan dalam interpretasi yang berbeda menyebabkan Pelindungan tidak efektif (Nanda, 1993). Pembaharuan dan perbandingan dalam penelitian ini bahwa Pelindungan yang dilakukan didasarkan pada konvensi internasional tentang pekerja migran, sedangkan pada penelitian ini, meskipun akan membahas dalam perspektif aturan hukum internasional sebagai dasar hukumnya, penelitian ini juga akan membahas dengan kajian aturan hukum nasional juga.

\section{B. METODE PENELITIAN}

Penelitian mengenai Pelindungan dan pemenuhan hak pekerja migran sektor informal dalam perspektif hukum nasional ini dibahas dengan metode penelitian hukum normatif (Normative Law Research), dimana penelitian dikaji dengan pendekatan konseptual (Conseptual Approach) dan Pendekatan Kasus (Case Approach).

Penelitian ini menggunakan beberapa sumber data, baik sumber data primer, sekunder, maupun tersier. Adapun bahan hukum sekunder yang digunakan yaitu : Undang-Undang Nomor 18 Tahun 2017 tentang Pelindungan Pekerja Migran Indonesia. Adapun bahan hukum sekunder dalam penelitian ini bersumber dari buku-buku, jurnal-jurnal ilmiah, 
Jurnal Pembangunan Hukum Indonesia

Volume 2, Nomor 2, Tahun 2020
Program Studi Magister Ilmu Hukum

Fakultas Hukum Universitas Diponegoro artikel, serta sumber online yang relevan dalam penelitian ini.

\section{HASIL DAN PEMBAHASAN}

\section{Pelindungan dan Pemenuhan Hak Pekerja} Migran Indonesia di Sektor Informal berdasarkan UU No.18 Tahun 2017

Indonesia sebagai negara hukum dalam memenuhi hak atas pelindungan terhadap warga negaranya didasarkan pada Undang-Undang Dasar Republik Indonesia Tahun 1945, dimana berbunyi "melindungi segenap bangsa Indonesia". Berdasarkan undang-undang tersebut, konsekuensinya setiap warga negara indonesia harus dibela dan dilindungi hak konstitusionalnya untuk memperoleh perlindungan hukum dan memperoleh penghidupan yang layak (Subiyanto,2011). Perlindungan tersebut termasuk bagi mereka para pekerja migran Indonesia yang bekerja di luar negeri. Berdasarkan Pasal 1 ayat (2) UU No.18 Tahun 2017, "Pekerja Migran Indonesia adalah setiap warga negara Indonesia yang akan, sedang, atau telah melakukan pekerjaan dengan menerima upar di luar wilayah Republik Indonesia."

Undang-undang ini merupakan ketentuan hukum yang dibentuk sebagai prosedur penempatan pekerja migran, seperti pelatihan pra-penempatan, program pra-keberangkatan, pemeriksaan kesehatan, perlindungan pekerja, penyelesaian perselisihan, pengawasan penempatan dan kegiatan pelindungan untuk pekerja migran Indonesia di luar negeri Indonesia (Tan, \& Shahrullah, 2017).
Banyaknya kasus yang terjadi kepada para pekerja migran Indonesia di luar negeri membuat pemerintah harus mengambil langkah untuk tetap melindungi warga negaranya di negara lain.

UU No. 18 Tahun 2017 tentang Pelindungan Pekerja Migran Indonesia merupakan undangundang yang disempurnakan dari undang-undang terdahulunya, yaitu UU No.34 Tahun 2004 tentang Penempatan dan Pelindungan Tenaga Kerja Indonesia di Luar Negeri. UU No. 18 Tahun 2017 memiliki beberapa kelebihan, yaitu pertama terkait definisi mengenai Tenaga Kerja Indonesia telah diperbaharui dengan istilah pekerja migran dan anggota keluarganya. Hal ini telah sesuai dengan isi Konvensi PBB 1990. Kedua terkait hak pekerja migran telah ditambahkan mengenai kebebasan berserikat, serta perlindungan sosial, ekonomi, dan hukum bagi para pekerja migran. Ketiga, UU No.34 Tahun 2004 meletakkan tanggung jawab pelatihan tenaga kerja hanya kepada PPTKIS, namun didalam UU No.18 tahun 2017 tanggung jawab pelatihan dan pendidikan juga menjadi tanggung jawab pemerintah. Keempat, adanya pembagian peran pemerintah daerah yang diperluas menjadi tingkat desa, kebupaten / kota, dan provinsi. Hal ini dilakukan untuk menetapkan standar perlindungan dan pemenuhan hak masing-masing pemerintahan. Kelima, terkait jaminan atas asuransi swasta bagi para pekerja migran diganti dengan BPJS Ketenagakerjaan. Keenam, mengenai penghapusan Kartu Tenaga Kerja Luar Negeri (KTKLN) yang rentan menjadi alat pemerasan terhadap pekerja 
migran. Ketujuh, adanya penguatan atase ketenagakerjaan di luar negeri dengan menyusun masing-masing tugas dan fungsinya. Kedelapan, melarang adanya rangkap jabatan yang dimiliki oleh pihak berwenang untuk penempatan dan perlindungan pekerja migran. Kesembilan, mengenai aturan turunan yang dibatasi dua tahun harus selesai, dimana ada aturan daru undang-undang sebelumnya yang melebihkannya, sehingga tidak terlaksanakan.

Adanya bentuk pelindungan terhadap pekerja migran Indonesia membuat Pemerintah Indonesia mengeluarkan aturan hukum mengenai pelindungan pekerja migran Indonesia. Perlu diketahui bahwa "Pelindungan" berbeda dengan "Perlindungan", dimana menurut Badan Pengembangan dan Pembinaan Bahasa, kata "Perlindungan" dan "Pelindungan" memiliki kata dasar yang sama, yaitu, "Lindung", namun kata imbuhan dan proses penurunannya berbeda. Berdasarkan proeses pengimbuhannya, kata "Perlindungan" memiliki makna "tempat berlindung" dan umumnya berhungan dengan kata kerja berlindung, sedangkan "Pelindungan" memiliki makna "perihal melindungi" (Badan Pengembangan dan Pembinaan Bahasa, 2015). Berdasarkan makna kata tersebut, maka UU No.18 Tahun 2017 tentang Pelindungan Tenaga Kerja Migran Indonesia memiliki makna bahwa undang-undang ini memiliki sifat hukum yang mengatur perihal melindungi para pekerja migran Indonesia. Adapun berdasarkan Pasal 1 ayat (5) UU No.18 Tahun 2017, berbunyi : "Pelindungan Pekerja
Migran Indonesia adalah segala upaya untuk melindungi kepentingan Calon pekerja Migran Indonesia dan/atau Pekerja Migran Indonesia dan keluarganya dalam mewujudkan terjaminnya pemenuhan haknya dalam keseluruhan kegiatan sebelum bekerja, selama bekerja, dan setelah bekerja dalam aspek hukum, ekonomi, dan sosial."

Berdasarkan pengklasifikasiannya, pekerja migran dibagi menjadi dua, yaitu pekerja migran sektor formal dan pekerja migran sektor informal. Pekerja migran sektor formal merupakan pekerja migran dengan kualifikasi yang cukup ketat, dimana mereka yang menjadi calon pekerja memiliki jenjang pendidikan menengah keatas, memiliki keahlian, serta pengalaman kerja. Sedangkan pekerja migran informal merupakan pekerja migran dengan tingkat pendidikan menengah kebawah serta sebagaian dari mereka tidak memiliki pengalaman pekerjaan (Prastiwi, 2016). Menurut data Badan Nasional Penempatan dan Perlindungan Tenaga Kerja Indonesia (BNP2TKI), penempatan Pekerja Migran Indonesia (PMI) selama tahun 2018 mencapai 283.640 pekerja, dimana dari jumlah tersebut, sebanyak 133.640 pekerja atau sekitar 47\% bekerja di sektor formal, sisanya berkiprah di sektor informal (Databoks,2019). Berdasarkan data tersebut, pekerja migran Indonesia di sektor informal lebih mendominasi, dimana 93.124 pekerjanya merupakan Penata Laksana Rumah Tangga (PLRT).

Permasalahan yang sering dihadapi oleh pekerja migran, khususnya pada sektor informal yaitu kasus pekerja migran tidak berdokumen, over 
Jurnal Pembangunan Hukum Indonesia

Volume 2, Nomor 2, Tahun 2020
Program Studi Magister Ilmu Hukum Fakultas Hukum Universitas Diponegoro charging, overstay, gaji tidak dibayar, penganiayaan, pemerkosaan, dan kasus pidana, dimana mayoritas menimpa perempuan pekerja migran Indonesia yang bekerja sebagai pekerja rumah tangga (PRT). Banyaknya kasus yang dihadapi oleh pekerja migran ini secara umum didasarkan pada tiga persoalan mendasar yang dihadapi para pekerja migran di sektor informal, yaitu : 1) Berstatus ilegal, dimana menyebabkan buruknya perlakuan aparat penegak hukum di negaraa tempat para pekerja migran berada, yang bertindak tidak sesuai standar hukum yang berlaku; 2) Pelindungan dari negara masih kurang efektif, sehingga rentan dijadikan objek pemerasan oknum petugas maupun agen penyedia; serta 3) Minimnya keterampilan yang menyebabkan tindak kekerasan sering terjadi.

Berdasarkan Pasal 6 ayat (1) UU No.18 Tahun 2017, terdapat 13 (tiga belas hak) yang dimiliki pekerja migran Indonesia, yaitu: Mendapatkan pekerjaan di luar negeri dan memilih pekerjaan sesuai dengan kompetensinya; Memperoleh akses peningkatan kapasitas diri melalui pendidikan dan pelatihan kerja; Memperoleh informasi yang benar mengenai pasar kerja, tata cara penempatan, dan kondisi kerja di luar negeri; Memperoleh pelayanan yang profesional dan manusiawi serta perlakuan tanpa diskriminasi pada saat sebelum bekerja selama bekerja, dan setelah bekerja; Menjalankan ibadah sesuai dengan agama dan keyakinan yang dianut; Memperoleh upah sesuai dengan standar upah yang berlaku di negara tujuan penempatan dan/atau kesepakatan kedua negara dan/atau
Perjanjian Kerja; Memperoleh pelindungan dan bantuan hukum atas tindakan yang dapat merendahkan harkat dan martabat sesuai dengan ketentuan peraturan perundang-undangan di Indonesia dan di negara tujuan penempatan; Memperoleh penjelasan mengenai hak \& kewajiban sebagaimana tertuang dalam Perjanjian Kerja; Memperoleh akses berkomunikasi; Menguasai dokumen perjalanan selama bekerja; Berserikat dan berkumpul di negara tujuan penempatan sesuai dengan ketentuan peraturan perundang-undangan yang berlaku di negara tujuan penempatan; Memperoleh jaminan pelindungan keselamatan dan keamanan kepulangan Pekerja Migran Indonesia ke daerah asal; dan Memperoleh dokumen \& Perjanjian Kerja Calon Pekerja Migran Indonesia dan/atau Pekerja Migran Indonesia.

Beberapa kasus kekerasan juga sering terjadi menimpa para pekerja migran Indonesia, khususnya di sektor informal yang bekerja sebagai PRT. Adapun kasus yang terjadi pada bulan Maret 2018, dimana seorang pekerja migran Indonesia bernama Santi R. Simbolon, ditemukan tewas meninggal di Paya Terubong, Malaysia. Adapun kasus yang dialami pekerja migran Indonesia asal NTT bernama Adelia Sau, ditemukan tewas setelah disiksa oleh majikannya di Malaysia. Berdasarkan 2 kasus tersebut, rentannya pekerjaan yang dilakukan para pekerja migran Indonesia ini sangat diharuskan untuk diberikan pelindungan bagi mereka. Pelindungan para pekerja migran Indonesia pada dasarnya mencakup tindakan pelindungan teknis oleh 
Jurnal Pembangunan Hukum Indonesia

Volume 2, Nomor 2, Tahun 2020
Program Studi Magister Ilmu Hukum

Fakultas Hukum Universitas Diponegoro
Perwakilan Diplomatik Republik Indonesia, yang ditujukan dengan tindakan berupa penyediaan rumah singgah yang aman dan repatriasi, tindakan fasilitator, serta rehabilitasi terhadap pekerja migran yang bermasalah (Sidik, \& Elvianti, 2018).

Berdasarkan Pasal 7 UU No.18 Tahun 2017, pelindungan calon pekerja migran Indonesia atau pekerja migran Indonesia meliputi: pelindungan sebelum bekerja; pelindungan selama bekerja; dan pelindungan setelah bekerja. Adanya pelindungan sebelum bekerja dikarenakan adanya beberapa kasus terkait proses perekrutan yang dilakukan, seperti proses dilakikan secara langsung sehingga tidak terdaftar oleh Pemerintah Kabupaten; calon pekerja migran ditempatkan lebih lama di penampunganl serta tidak mendapatkan informasi terkait hak-haknya maupun perjanjian kerja. Perlindungan selama bekerja dibutuhkan karena terkait kasus-kasus yang sering terjadi, seperti keterlambatan pembayaran atau tidak sesuaii perjanjian kerja, penganiayaan dan bentuk kekerasan lainnya, penahanan dokumen, serta pembatasan komunikasi. Perlindungan setelah bekerja juga perlu diupayakan, karena terkait beberapa permasalahan saat kepulangan, seperti tertahan di kota transit, adanya pungutan liar, dan permasalahan lainnya (Prihatinah, Asyik, \& Kartono, 2012).

Berdasarkan kasus-kasus tersebut, pentingnya pelindungan dan pemenuhan hak pekerja migran Indonesia selayaknya perlu dipantau terus menerus. Pemantauan ini diperlukan agara pelindungan dan pemenuhan hak dapat terjamin. Pasal 1 ayat (6) UU
No.18 Tahun 2017, berbunyi : "Pelindungan Sebelum Bekerja adalah keseluruhan aktivitas untuk memberikan pelindungan sejak pendaftaran sampai keberangkatan." Berdasarkan Pasal 1 ayat (7) UU No.18 Tahun 2017 berbunyi : "Perlindungan Selama Bekerja adalah keseluruhan aktivitas untuk memberikan pelindungan selama pekerja migran Indonesia dan anggota keluarganya berada di luar negeri". Serta berdasarkan Pasal 1 ayat (8) UU No. 18 Tahun 2017 berbunyi: "Pelindungan Setelah Bekerja adalah keseluruhan aktivitas untuk memberikan pelindungan sejak pekerja migran Indonesia dan anggota keluarganya tiba di debarkasi di Indonesia hingga kembali ke daerah asal, termasuk pelayanan lanjutan menjadi pekerja produktif.

Adapun terhadap kasus yang disebutkan diatas bahwa melalui Kementerian Luar Negeri dan BNP2TKI, selain upaya memulangkan jenazah, hal lain yang dilakukan adalah mengupayakan hakhaknya oleh majikan, seperti proses hukumnya disana, upah-upah yang belum terbayarkan, serta hak-hak lainnya. Hal tersebut didalam Pasal 24 ayat (1), berbunyi: "Perlindungan Setelah bekerja sebagaimana dimaksud dalam Pasal 7 huruf (c) meliputi: fasilitas kepulangan sampai daerah asal; penyelesaian hak pekerja migran Indonesia yang belum terpenuhi; fasilitas pengurusan pekerja migran Indonesia yang sakit dan meninggal dunia rehabilitasi sosial dan reintegrasi sosial; dan pemberdayaan pekerja migran Indonesia dan keluarganya." Banyaknya permasalahan yang timbul bagi para 
Jurnal Pembangunan Hukum Indonesia

Volume 2, Nomor 2, Tahun 2020
Program Studi Magister Ilmu Hukum Fakultas Hukum Universitas Diponegoro pekerja migran Indonesia dari sektor informal, maka harus ada MoU yang dibuat sebelum melakukan penempatan. Meskipun undang-undang sudah tegas dalam menjabarkan dan menjelaskan bentuk-bentuk perlindungan yang diberikan, namun dalam hal ini perlu adanya suatu perjanjian tertulis antara pemerintah negara tujuan dan Pemerintah Republik Indonesia, agar jaminan atas perlindungan pekerja migran Indonesia dapat terlindungi.

\section{Analisis Yuridis Pelindungan dan Pemenuhan} Pekerja Migran Indonesia di Sektor Informal Berdasarkan Teori Bekerjanya Hukum di Masyarakat

Kasus yang terjadi pada permasalahan pekerja migran Indonesia menimbulkan pertanyaan mengenai apakah pelindungan dan pemenuhan terhadap pekerja migran Indonesia tersebut sudah efektif atau belum. Berdasarkan permasalahan tersebut, perlu dipahami mengenai efektifnya suatu hukum. Secara yuridis, untuk mengukur efektifnya suatu hukum yang dilaksanakan di masyarakat di tinjau dengan menggunakan Teori Bekerjanya Hukum di Masyarakat. Teori Bekerjanya Hukum di Masyarakat dikemukakan oleh Robert B.Seidman dan William B. Chambliss, dimana dalam bukunya berjudul "Law Order and Power", memberikan pengertian bahwa teori ini melihat keseimbangan fungsi hukum. Menurut Seidman, terdapat 3 (tiga) faktor yang menjadi dasar berkerjanya hukum di masyarakat, yaitu : Lembaga Pembuat Peraturan (Law Making Process); Lembaga Penerap Peraturan
(Law Implementing Process), dan Pemegang Peran (Role Occupant) (Seidman, \& Chambliss, 1971).

Faktor pertama yaitu Lembaga Pembuat Peraturan (Law Making Process); merupakan lembaga yang berwenang melegitimasi pembuatan perundang-undangan (Seidman \& Chambliss, 1971). Lembaga pembuat peraturan terkait penelitian ini yaitu Dewan Perwakilan Rakyat Republik Indonesia sebagai lembaga legislatif. Adapun DPR didalam UUD 1945 memiliki 3 (tiga) fungsi, yaitu fungsi legislasi, anggaran, dan pengawasan. Fungsi legislasi mempertegas kedudukan DPR sebagai lembaga legislatof yang menjalankan kekuasaan membentuk undang-undang (Hantoro, 2012). Hal tersebut berarti UU No.18 Tahun 2017 merupakan produk hukum yang dibuat DPR dalam rangka membentuk aturan hukum untuk memberikan pelindungan dan pemenuhan hak pekerja migran Indonesia.

Faktor kedua yaitu Lembaga Penerap Peraturan (Law Implementing Process) ; merupakan lembaga pelaksana yang secara tegas melaksanakan perintah yang ada dalam undangundang tanpa adanya diskriminasi (Seidman \& Chambliss, 1971). Berdasarkan Pasal 39 - 43 UU No.18 Tahun 2017, Pemerintah Pusat, Pemerintah Daerah Provinsi, Pemerintah Daerah Kabupaten/Kota serta Pemerintah Desa memiliki tugas dan tanggung jawab memberikan jaminan pelindungan, pembinaan, pelaksanaan, penyelenggara, serta pemenuhan hak-hak pekerja migran Indonesia. Salah satu contoh bentuk 
pemenuhan hak yang diberikan melalui Pemerintah yaitu dengan menyelenggarakan pendidikan dan pelatihan kerja. Pendidikan dan pelatihan kerja ini berfungsi sebagai bekal yang diberikan kepada pekerja migran Indonesia. Baik Pemerintah Pusat, Pemerintah Daerah Provinsi, Pemerintah Daerah Kabupaten/ Kota, maupun Pemerintah Desa memiliki tugas dan tanggung jawabnya masing-masing dalam pemenuhan hak pekerja migran Indonesia berdasarkan UU No.18 Tahun 2017.

Pelaksana tugas pemerintah tersebut kemudian dibantu oleh lembaga-lembaga. Berdasarkan Pasal 44 UU No.18 Tahun 2017, "Pelaksana tugas pemerintah di bidang Pelindungan Pekerja Migran Indonesia diselenggarakan oleh kementerian dan Badan. Adapun kementerian yang dimaksud yaitu Kementerian Ketenagakerjaan bersama Kementerian Luar Negeri. Sedangkan badan yang menjadi pelaksana tugas pemerintah yaitu Badan Nasional Penempatan dan Perlindungan Tenaga Kerja Indonesia (BNP2TKI).

Lembaga dan pihak terkait penanganan pekerja migran Indonesia pada dasarnya di bagi menjadi beberapa tingkatan berdasarkan teritorinya. Adapun di tingkatan daerah terdiri dari : Pemerintah Desa/Kelurahan, Dinas Tenaga Kerja Kabupaten/Kota, Perusahaan Penyalur Tenaga Kerja Indoneisa, dan Pemerintahan Kabupaten/Kota. Pada tingkat provinsi, adapun lembaga dan pihak terkait yaitu: Dinas Tenaga Kerja Provinsi, Pemerintah Provinsi, dan Badan Pelayanan Penempatan dan Perlindungan Tenaga Kerja Indonesia (BNP3TKI).
Pada tingkat nasional, lembaga dan pihak terkait tersebut yaitu: Kementerian Ketenagakerjaan, Lembaga Sertifikasi, Lembaga Swadaya Masyarakat dan Lembaga Bantuan Hukum, Komisi Informasi, Pos Pelayanan Tenaga Kerja Indonesia, dan Badan Nasional Penempatan dan Perlindungan Tenaga Kerja Indonesia. Serta pada tingkat internasional ditangani oleh Perwakilan Indonesia di Luar Negeri, yang dalam hal ini para Diplomatik dan Konsulat dibawah naungan Kementerian Luar Negeri.

Faktor ketiga yaitu Pemegang Peran (Role Occupant); yaitu masyarakat yang diharapkan mampu mentaati hukum. Fungsi pemegang peran dalam hal ini sebagai umpan balik kepada lembaga pembuat peraturan dan lembaga penerap peraturan. Berkaitan dengan penelitian ini, pemegang peran merupakan masyarakat yang bertindak sebagai respon terhadap aturan yang dibuat. Masyarakat diharapkan dapat memahami dan mematuhi aturanaturan tersebut. Berdasarkan penelitian ini pemegang peran ditujukan kepada calon pekerja migran Indonesia, pekerja migran Indonesia, serta keluarganya.

Berdasarkan teori bekerjanya hukum dimasyarakat terkait penelitian ini, pada dasarnya permasalahan mengenai kasus-kasus yang sering terjadi pada pekerja migran Indonesia adalah terkait adanya kelalaian dalam bertindak antara lembaga penerap sanksi dan pemegang peran. Aturan hukum yang dibuat oleh lembaga pembuat peraturan pada dasarnya sudah berisi komponen-komponen bentuk pelindungan dan pemenuhan hak pekerja migran 
Jurnal Pembangunan Hukum Indonesia

Volume 2, Nomor 2, Tahun 2020
Program Studi Magister Ilmu Hukum Fakultas Hukum Universitas Diponegoro
Indonesia, baik hak-hak yang diperoleh, tanggung jawab para lembaga dan pihak, sampai kepada sanksi pidana yang ditetapkan. UU No.18 Tahun 2017 tentang Pelindungan Pekerja Migran merupakan undang-undang baru menggantikan undang-undang terdahulunya, yaitu UU No.39 Tahun 2004 tentang Penempatan dan Pelindungan Tenaga Kerja Indonesia di Luar Negeri. Ketentuan didalam UU No.18 Tahun 2017 ini pada dasarnya memperbaiki kelemahan yang ada didalam undangundang sebelumnya. UU No.18 Tahun 2017 merupakan sebuah regulasi yang dapat dijadikan patokan oleh para pekerja migran Indonesia.

Terkait mengapa pelindungan dan pemenuhan hak yang diberikan kepada pekerja migran Indonesia masih saja bermasalah yaitu dikarenakan masingmasing pihak, baik lembaga atau masyarakat dianggap lalai dalam menjalankan dan memahami aturan hukum yang dibuat. Konsep pelindungan pekerja migran Indonesia dianggap bahwa bentuk pelindungan tersebut merupakan tanggung jawab pemerintah sebagai pemangku kekuasaan dalam negara (Nasution, 2017). Lembaga penerap peraturan, dalam hal ini dianggap lalai karena sering kali pada kasusnya mendapati kasus perusahaan penyalur tenaga kerja Indonesia yang bermasalah, dimana perusahaan ini tidak bersertifikasi dan tidak mematuhi standar hukum yang diterapkan. Hal ini juga terkait lambatnya penanganan kasus-kasus yang terjadi pada para pekerja migran.

Selain kelalaian oleh lembaga penerap peraturan, kelalaian juga seringkali terjadi masyarakat sebagai pemegang peran. Kelalai tersebut biasanya disebabkan karena kurangnya informasi yang didapatkan oleh para calon pekerja migran, pekerja migran, serta keluarganya. Kurangnya informasi tersebut seringkali dimanfaatkan oleh para oknum perusahaan penyedia tenaga kerja yang tidak bertanggung jawab, dimana mereka mengiming-imingkan sesuatu, yang kemudian berdampak pada munculnya kasus-kasus seperti tenaga kerja Indonesia yang ilegal. Calon pekerja migran serta keluarganya dalam hal ini harus memahami aturan hukum yang dibuat, meski pada faktanya beberapa kalangan calon pekerja migran, khususnya di sektor infomal berlatar belakang pendidikan yang minim, hal ini harus dibarengi peran pemerintah sebagai lembaga yang bertanggung jawab untuk melindungi dan memenuhi hak-hak calon pekerja migran, pekerja migran, dan keluarganya.

Pemahaman mengenai teori bekerjanya hukum di masyarakat pada penelitian ini untuk menganalisis bagaimana pemegang peran didalam masyarakat akan bertindak, dimana hal tersebut harus ditinjau dalam hubungan masing-masing pihak. Upaya-upaya yang dilakukan oleh pemerintah harusnya menjadi respon terhadap masyarakat, khususnya yang membutuhkan pekerja. Umpan balik antara ketiga faktor tersebut diharapkan dapat bertindak masing-masing dan saling berhubungan untuk memenuhi berfungsinya hukum. Keberadaan Lembaga Swadaya Masyarakat (LSM) sebagai civil society juga mengambil peran adanya turut serta 
Jurnal Pembangunan Hukum Indonesia

Volume 2, Nomor 2, Tahun 2020
Program Studi Magister Ilmu Hukum Fakultas Hukum Universitas Diponegoro pihak lain dalam menyeimbangkan kekuatan negara dimana LSM ini menjadi kekuatan tersendiri dalam masyarakat agar dapat memperoleh hak-hak mereka para pekerja migran Indonesia dan keluarganya (Setyoningsih, Fitriyah, \& Hermini, 2013).

Permasalahan mengenai sering munculnya kasus-kasus yang terjadi terhadap tenaga kerja migran terkadang tidak hanya persoalan mengenai tenaga kerja Indonesia yang ilegal, melainkan beberapa kasus diluar perkiraan yang terjadi selama pekerja migran tersebut. Meskipun begitu, pemerintah dalam hal ini harus bertindak memegang perannya dalam upaya pelindungan dan pemenuhan hak pekerja migran Indonesia tersebut, secara khusus kepada pekerja migran Indonesia di sektor informal, karena mereka rentan sekali dimanfaatkan oleh oknum tidak bertanggung jawab karena ketidaberdayaan mereka. Upaya tersebut dilakukan agar dapat menciptakan kesejahteraan di masyarakat, khususnya calon pekerja migran, pekerja migran, dan keluarganya.

\section{SIMPULAN}

Berdasarkan penelitian ini, seringnya terjadi kasus yang melibatkan pekerja migran Indonesia diluar negeri khususnya di sektor informal yang bekerja sebagai pekerja rumah tangga, pada dasarnya dikarenakan minimnya informasi serta lambatnya penanganan yang dilakukan oleh pemerintah. UU No.18 Tahun 2017 sebagai aturan hukum mengenai pelindungan dan pemenuhan hak pekerja migran merupakan sebuah aturan hukum yang telah disempurnakan dari UU No.39 Tahun 2004. UU No.18 Tahun 2017 pada dasarnya sudah memiliki komponen-komponen yang memadai terkait pelindungan dan pemenuhan hak pekerja migran, sehingga aturan hukum ini diharapkan dapat mampu untuk dipahami oleh semua kalangan masyarakat dan pihak lainnya.

Peran-peran dalam menjalankan fungsinya juga harus bertindak saling terhubung antara satu dengan yang lainnya, sehingga bekerjanya hukum dapat terlaksana dengan baik. Peran-peran di lembaga-lembaga dan pihak-pihak lainna diharapkan mampu menjalankan tugas tanggung jawabnya dengan baik. Hal ini juga dibarengi dengan penyampaian informasi yang tepat dan akurat kepada masyarakat agar masyarakat mengetahui informasi yang tepat. Pada kasus-kasus yang yang sering terjadi pada pekerja migran Indonesia ini disebabkan karena kelalaian pemerintah dalam menanggapi respon yang ada dilapangan, baik terhadap penindakan perusahaan penyedia tenaga kerja, serta responnya di tempat para pekerja migran yang menurut beberapa pekerja migran mereka sulit mengakses informasi dikarenakan berbagai hal. Oleh karena itu, diperlukan respon pemerintah untuk tanggap terhadap para pekerja migran Indonesia ini.

Peran calon pekerja migran Indonesia, pekerja migran Indonesia, serta keluarganya juga diharapkan mampu untuk memahami dan merespon dengan baik aturan hukum. Masyarakat sebagai pemegang peran juga harus berperan aktif dalam menyaring informasi 
yang akurat yang dibutuhkan, sehingga terhindar dari berbagai permasalahan.

\section{DAFTAR PUSTAKA}

\section{BUKU}

Asikin, Z (2004). Dasar-dasar Hukum Perburuhan. Jakarta : PT. Raja Grafindo Persada.

Seidman, Robert Benjamin., \& Chambliss, William Joseph (1971). Law, Order, and Power. Phillipines: Addison Wesley Publishing Company.

\section{J URNAL}

Arpanggi. (2016). Pelindungan Hukum Terhadap Tenaga Kerja Indonesia di Luar Negeri. J urnal Pembaharuan Hukum, Vol.3, (No.1), pp.149156.

Hadi, S. (2008). Sekuritisasi dan Upaya Peningkatan Pelindungan terhadap Tenaga Kerja Indonesia. J urnal Hukum Internasional Labour Law, Vol.5, (No.4), pp.741-765.

Hantoro, Novianto M. (2012). Kajian Yuridis Pembentukan Undang-Undang Tentang Dewan Perwakilan Rakyat Indonesia. Jurnal Negara Hukum, Vol.3, (No.2), pp.153-180.

Hidayat. (2017). Pelindungan Hak Tenaga Keja Indonesia Di Taiwan Dan Malaysia Dalam Perspektif Hak Asasi Manusia. J urnal HAM, Vol.8, (No.2), pp.105-115.

Nanda, Veid P. (1993). The Protection of the Rights of Migrant Workers : Unfinished Business. Asian and Pasific Migration Journal, Vol.2, (No.2), pp.161-177.
Nasution, Robby D. (2017). Model Advokasi LSM JKPS Cahaya Terhadap Buruh Migran Asal Kabupaten Ponorogo. Masalah - Masalah Hukum, Jilid 46, (No.1), pp.30-40.

Prastiwi, Lustina F. (2016). Analisis Pekerja Migran dan Nonmigran Perkotaan Pada Sektor Formal dan Sektor Informal di Indonesia. J urnal IImiah Mahasiswa FEB Universitas Brawijaya, Vol.4, (No.1), pp.1-22.

Prihatinah, Tri Lisiani., Asyik, Noor., \& Kartono. (2012). Kendala Perlindungan Terhadap Buruh Migran di Kabupaten Cilacap. Jurnal Dinamika Hukum, Vol.12, (No.2), pp.312-320.

Setyoningsih, Endang., Fitriyah, \& Hermini. (2013). Peran LSM Migrant CARE dalam Membantu TKI Bermasalah. Journal of Politic And Government Studies, Vol.2, (No.1), pp.261270.

Sidik, Jihan Djafar., \& Elvianti, Witri. (2018). The Consignment of Indonesia Migramt Workers in Saudi Arabia and Its Resilence : Examining the Impacts of Indonesia's Moratorium Policy. Andalas J ournal of International Studies, Vol.7, (No.1), pp.14-31.

Subiyanto. (2011). Peran Negara dalam Hubungan Tenaga Kerja di Indonesia. J urnal Pendidikan dan Kebudyaan, Vol.17, (No.6), pp.705-718.

Tan, Win Sherly., \& Shahrullah, Rina Shahriyani. (2017). Human Rights Protection For Indonesia Migrant Workers : Challenges for ASEAN. Mimbar Hukum, Vol.29, (No.1), pp.123-134. 
Wright, Chris F., \& Clibborn, Stephen. (2019).

Migrant Labour and Loow-Quality Work : A Persistent Relationship. Journal of Industrial Relations, Vol.61, (No.2), pp.157-175.

Widyawati, A. (2018). Legal Protection Model for Indonesian Migrant Workers. Journal of Indonesian Legal Studies, Vol.3, (No.2), pp.291-304.

Yusitarani Safrida., \& Sa'adah, Nabitatus. (2020). Analisis Yuridis Pelindungan Hukum Tenaga Migran Korban Perdaganagan Manusia oleh Pemerintah Indonesia. Jurnal Pembangunan Hukum Indonesia, Vol.2, (No.1), pp.24-37.

\section{SUMBER ONLINE}

Badan Pengembangan dan Pembinaan Bahasa. (2015). Perbedaan Kata Perlindungan dan Pelindungan. Retrived from http://badanbahasa.kemdikbud.go.id/lamanbah asa/content/apa-perbedaan-maknaperlindungan-dan-pelindungan

Databoks. (2019). 47\% Pekerja Migran Indonesia Berkiprah di Sektor Formal Sepanjang 2018. Retrived from https://databoks.katadata.co.id/ datapublish/2019/07/30/47-pekerja-migranindonesia-berkiprah-di-sektor-formalsepanjang-2018 